\title{
CORRECTION
}

\section{Correction to: Sustainability efforts, index recognition, and stock performance}

\author{
Moonsoo Kang ${ }^{1}$ (]) K. G. Viswanathan ${ }^{2} \cdot$ Nancy A. White ${ }^{2} \cdot$ Edward J. Zychowicz $^{2}$
}

Published online: 9 April 2021

๑) Springer Nature Limited 2021

Correction to: Journal of Asset Management

https://doi.org/10.1057/s41260-020-00202-0

After publication online, it was noticed that the affiliations of authors K. G. Viswanathan, Nancy A. White and Edward $\mathrm{J}$. Zychowicz were incorrectly given as Brooklyn College of the City University of New York, USA. The correct affiliations are given in the contact details section.

Publisher's Note Springer Nature remains neutral with regard to jurisdictional claims in published maps and institutional affiliations.

The original article can be found online at https://doi.org/10.1057/ s41260-020-00202-0.

Moonsoo Kang

moonsoo.kang@brooklyn.cuny.edu

1 Brooklyn College of the City University of New York, 2900

Bedford Ave, Brooklyn, NY 11210, USA

2 Hofstra University, Hempstead, NY, USA 